\title{
The Effect of Breed, Age and Fasting Status on Macro-nutrient Composition of Meat from Goat Breeds of North-Western Nigeria
}

\author{
M. Jibir**1, W.A. Hassan ${ }^{1}$, S.A. Maigandi ${ }^{1}$, S. Garba ${ }^{1}$ and J.B.Adeyaniju ${ }^{2}$ \\ ${ }^{1}$ Department of Animal Science, ${ }^{2}$ Department of Veterinary Medicine, Surgery and \\ Theriogenology, Usmanu Danfodiyo University, Sokoto
}

[*Author of Correspondence: emjibir@yahoo.com]

\begin{abstract}
Carcasses of 32 male goats matching Conformation Score 3 of the Australian standard for live goat evaluation, were randomly assigned to a $2 \times 2 \times 2$ factorial experiment involving two breeds (Sahel, Sokoto Red), two ages (young, mature) and two fasting states (fasted, non-fasted) with four replicates. one and a half centimeter thick samples of the Longissimus dorsi muscle cut between the $12^{\text {th }}$ and $13^{\text {th }}$ ribs of the right halves of the carcasses were analyzed according to AOAC (1990) and found to contain an average of $75.59,19.19,3.67$ and $1.55 \%$ moisture, protein, fat and total ash, respectively. None of the nutrients was affected significantly $(\mathrm{P}>0.05)$ by breed, age and fasting status $(\mathrm{P}>0.05)$. This may imply that the three factors need not feature as major considerations in the choice of goat meat for nutritional advantage in the study area.
\end{abstract}

\section{INTRODUCTION}

Goats are primarily kept for meat in Nigeria and most other developing countries (Taneja, 1982; Terrill, 1986), where they form an integral part of the largely subsistent agricultural system. The potential of goat meat production for improving the nutritional and socio-economic well-being of human populace of developing countries had been well documented (Griffin et al., 1992; Gadiyaram and Kannan, 2004).

In Nigeria, about 11.6 million goats are slaughtered to produce about $147.07 \times 10^{3}$ metric tonnes of meat annually (FAO, 2005). Adu (1985) earlier noted that about $30 \%$ of the total lean meat consumption in Nigeria came from goats. The Sokoto Red originated in Northwestern Nigeria and is the predominant breed in Nigeria, while the Sahel goat originated in Sahelian North-West of Africa (Mason, 1988) and found along the northern fringes of the country. Since the Sokoto Red and the Sahel constitute the major goat breeds slaughtered in Nigeria. A choice between the meats of these breeds and age-related changes in macromolecular composition of their meats will allow for competitive maximization of nutritional and economic advantage.

However, research into the various aspects of goat production is generally neglected
(Tshabalala et al., 2003). This dearth of information is more acute in respect of goat meat. It was for this reason that the need arose to evaluate meat from goats of the NorthWestern Nigeria for their basic nutritional components.

\section{MATERIALS AND METHODS}

Experimental Layout: Carcasses of 32 male goats conforming to body condition Score 3 of the Australian standard for live goat evaluation, were randomly allocated to a completely randomized $2 \times 2 \times 2$ factorial design involving two breeds (Sahel, Sokoto Red), two ages (Young, mature) and two fasting states (Fasted, non-fasted) with four replicates. Breed selection was based on classical phenotypic characteristics as described by Ngere et al. (1984) and Mason (1988). Mature goats are those having a pair of permanent incisors, while young are those with milk teeth only. Fasted animals were allowed only water in the last 12 hours before slaughter. The non-fasted ones were continued on the ad libitum diet of $2: 1 \mathrm{v} / \mathrm{v}$ mix of cowpea husk and wheat offal that was fed to all experimental animals during an initial 24 hour resting period.

Preparation of Samples: One and a half centimeter thick meat samples were excised from the Longissimus dorsi, at the loin eye cut 
between the $12^{\text {th }}$ and $13^{\text {th }}$ ribs of the right sides of the carcasses. Samples were tightly packed individually in polythene bags and frozen at $7^{\circ} \mathrm{C}$ for 24 hours, after which the samples were analyzed for moisture, protein, fat and ash according to procedures outlined by AOAC (1990). Each meat sample was replicated three times.

Data Analysis: Data were analyzed as a completely randomized design with a factorial arrangement of treatments, using the GLM univariate procedure of SPSS (1999). A fixed model, involving the main effects of breed, age and fasting was utilized. All possible interactions between the factors were excluded from the final model as they were statistically not significant. The statistical model for the analysis was:

$\begin{array}{rll}\mathrm{Y}_{\mathrm{ijkl}} & = & \mu+\beta_{\mathrm{i}}+\mathrm{A}_{\mathrm{j}}+\mathrm{F}_{\mathrm{k}}+\mathrm{E}_{\mathrm{ijkl}} \\ \mathrm{Y}_{\mathrm{ijjkl}} & = & \text { the estimated parameter } \\ \mu & = & \text { population mean } \\ \beta_{\mathrm{i}} & = & \text { fixed effect of breed }(\mathrm{i}=1,2) \\ \mathrm{A}_{\mathrm{j}} & = & \text { fixed effect of age }(\mathrm{j}=1,2) \\ \mathrm{F}_{\mathrm{k}} & = & \text { fixed effect of fasting }(\mathrm{k}=1,2) \\ \mathrm{E}_{\mathrm{ij} \mathrm{j} k 1} & = & \text { Random error }\end{array}$

\section{RESULTS}

The overall percent levels of moisture, protein, fat and total ash in the lean meat of the experimental animals were $75.59,19.19,3.67$ and $1.55 \%$, respectively (Table 1 ). None of these components was significantly affected by breed, age or fasting status ( $\mathrm{P}>0.05)$.

Table 1: Chemical composition of lean (\%) according to breed, age and fasting status of goats

\begin{tabular}{lllll}
\hline \multicolumn{4}{c}{ Macro-Nutrient } \\
\hline Factor & Moisture & Protein & Fat & Ash \\
\hline Overall & 75.59 & 19.19 & 3.67 & 1.55 \\
SE & 0.67 & 0.64 & 0.17 & 0.12 \\
Breed & & & & \\
$\quad$ Sokoto Red & 75.66 & 18.94 & 3.72 & 1.68 \\
$\quad$ Sahel & 75.53 & 19.44 & 3.63 & 1.41 \\
SE & 0.63 & 0.63 & 0.15 & 0.12 \\
Age & & & & \\
$\quad$ Young & 75.38 & 19.65 & 3.63 & 1.35 \\
$\quad$ Mature & 75.81 & 18.73 & 3.72 & 1.74 \\
SE & 0.64 & 0.62 & 0.16 & 0.12 \\
Fasting & & & & \\
Status & & & & \\
$\quad$ Fasted & 75.94 & 18.84 & 3.66 & 1.56 \\
$\quad$ Non-Fasted & 75.25 & 19.53 & 3.69 & 1.53 \\
SE & 0.64 & 0.52 & 0.16 & 0.13 \\
\hline
\end{tabular}

\section{DISCUSSION}

That breed, age and fasting status did not significantly affect the value of any of the macro nutrients attests to the veracity of the conclusion by Geay et al. (2000) that the chemical composition of muscles is relatively constant. Since this observation was based on all muscles, it should be expected to hold more truth when animals of the same species were compared.

The $75.59 \%$ observed for moisture content fell within the $65-80 \%$ range reported for fresh muscle of meat animals by Forrest et al. (1975) and agreed more closely with the $74-76 \%$ reported for goat muscles (Devendra, 1988). Mean percent protein observed in the present report (19.19) agreed with the figures of Forrest et al. (1975) for fresh meat, Geay et al. (2000) on ruminant muscle and Gaili et al. (1972) on muscle of Sudan Dessert goats. The Mean fat composition of $3.67 \%$ was within the figures reported by Forrest et al. (1975) and Geay et al. (2000), but fell outside the range of 5.5-19.06\% reported by Gaili et al. (1972). Mean ash content of the meat samples analyzed was $1.5 \%$. This value, although slightly higher than the $1.0-1.1 \%$ assumed in many nutrient evaluation of lean meat, was within the 1-2\% reported of muscles by Geay et al. (2000).

Conclusion: Chemical composition of lean was unaffected by any of the treatment factors investigated. This may imply that the breed, age and fasting status need not feature as major considerations in the choice of goat meat for nutritional advantage in the study area.

\section{REFERENCES}

A.O.A.C. (1990) Association of Official Analytical Chemists. Official Methods of Analysis. (15th ed.) Arlington, Virginia, USA.

Adu, I.F. (1985) Feedlot fattening of sheep and goats: the Shika experience. In: Small Ruminant Production in Nigeria. Proc. of a National Conf., Oct. 6-10 Zaria, Nigeria.

Devendra, C. (1988) The nutritional value of goat meat. In: Devendra, C. (ed). Goat Meat Production in Asia. Proc. of a workshop held in Tando Jam Pakistan, March 13-18, 1988. IDRC, Canada, p. 76 - 86. 
FAO (2005) Food and Agriculture Organization of the United Nations. FAO statistical database. http://aps. FAO. Org. cited $16 / 06 / 06$.

Forrest, J.C., Aberle, E.D., Hedrick, H.B., Judge, M.D. and Merkel, R. A. (1975) Principles of Meat Science. W.H. Freeman and Co. San Francisco. 417 pp.

Gadiyaram, K.M. and Kannan, G. (2004) Comparison of textural properties of low-fat chevon, beef, pork, and mixed-meat sausages. 34 (Supplement 1) OSouth African Society for Animal Science Peerreviewed paper: $8^{\text {th }}$ International Conference on Goats, 212 pp.

Gaili, E.S.E., Ghanem, Y.S. and Mukhtar, A.M.S. (1972) A comparative study of some carcass characteristics of Sudan Desert sheep and goats. Anim. Prod., 14: 351 - 357.

Geay, Y., Bauchart, D., Hocquette, J. and Culioli, J. (2000) Effect of nutritional factors on biochemical, structural and metabolic characteristics of muscles in ruminants, consequences on dietetic value and sensorial qualities of meat. Retrieved from www.edpsciences.org on 12/06/2006

Griffin, C.L., Orcutt, M.W., Riley, R.R., Smith, G.C., Savell, J.W. and Shelton, M. (1992) Evaluation of palatability of lamb, mutton and chevon by sensory panels of various cultural backgrounds. Small Rum. Res., 8: 67-74.

Mason, I.L. (1988) A World Dictionary of Livestock Breeds: Types and Varieties. C.A.B. International. $348 \mathrm{pp}$.

Ngere, L.O., Adu, I.F. and Okubanjo, I.O. (1984) The indigenous goats of Nigeria. Animal Genetic Resources Information, FAO, Rome, 3: 1-9.

SPSS (1999) Statistical Package for the Social Sciences. Version 10.0. SPSS Inc.

Taneja, G.C. (1982) Breeding goats for meat production. In: Proc. of the 3rd Int. Conf. on Goat Prod. and Diseases, January, 5-9. Tucson, Arizona, USA. P. 27-30.

Terrill, C.E. (1986) Trends in sheep and goat production over the past 20 years. In: Timon, V.M. and Harahan, J.P. (eds). Small Ruminant Production in Developing Countries. Proc. of an expert consultative forum, held in Sofia, Bulgaria. July 8-12. FAO Anim Prod. and Health Paper, 58, FAO, Rome. p. 1-11.

Tshabalala, P.A., Strydom, P.E., Webb, E.C. and de Kock, H.L. (2003) Meat quality of designated South African indigenous goat and sheep breeds. Meat Science, 65 (1): 563 570. 